\title{
Post-industrial redevelopment and the mega-region: new strategies for the sustainable city of the 21 st century
}

\author{
P. J. Armstrong \& P. H. Kapp \\ School of Architecture, University of Illinois Urbana-Champaign, USA
}

\begin{abstract}
Cities throughout the U.S., Canada, and Europe are repurposing their abandoned post-industrial districts for the 21 st century urban living and the innovation economy. As post-industrial cities redefine themselves, they must consider the consolidation of resources and scale in response to constantly changing economic and demographic variables. This means that, paradoxically, cities may need to physically shrink to create density before they can grow economically.

This paper, therefore, presents the post-industrial redevelopment phenomenon that is occurring in North America and Europe and discusses how it is redefining post-industrial cities as sustainable and innovative epicenters. It examines how post-industrial infrastructure is being redeveloped through initiatives in transportation, sustainability, and manufacturing that will promote economic, social, and ecological benefits to the metabolisms of cities and regions especially in the U.S. Midwest.

Keywords: post-industrial, sustainability, transportation, mega-region, epicentre, historic preservation.
\end{abstract}

\section{Introduction}

For the past fifteen years, manufacturing cities throughout the United States have experienced a significant decline. According to the U.S. Bureau of Labor Statics' Establishment Survey, the share of manufacturing employment in 1950 was about $35 \%$ and in 2004 it was about 13\% (Fisher and Rupert [1]). The current recession, accelerated by the financial collapse on September 15, 2008, has exacerbated this decline forcing mass closings of manufacturing facilities and layoffs of workers. Leading economists agree that the effects of this 
recession will be long-lasting and it will challenge the country to restructure the economy. Moreover, the recession is emphasizing the fact that the majority of the manufacturing base of the American economy is relocating in order to capitalize on the inexpensive costs and labor proffered by developing countries.

The consequences of globalization are far reaching and deep. The global economy will now compel all facets of the American economy to focus on what it has in the past done very well-innovate. In order for America to transform from an industrial-based economy to an innovation-based economy, whole-scale changes will need to be made in every aspect of society. Changes will also include the design of our cities as well. Larger U.S. cities such as Detroit, New Orleans, St. Louis and Buffalo, New York have all experienced extreme economic calamities, steep population declines, and drastic reduction in income and corporate tax receipts. As these cities continue to reassess their standing in a post-industrial age, their urban form will need to be assessed as well. Can these cities retain their current geographical size? Is the current urban form of these cities appropriate for the new economy? These are the fundamental questions facing American cities today.

Today, former U.S. manufacturing cities - particularly those located in the Midwest and Northeast-are grappling with an increasing unemployed workforce, declining populations, a large inventory of unoccupied buildings, and a decaying infrastructure. From this crisis, can we transform our industrial cities into centers of creativity and innovation? Finally, can we use this current economic crisis to correct the environmental mistakes of the past in our cities?

These issues are not only found in large industrial cities; mid-size cities in the U.S. have encountered the same challenges. While each city has employed different strategies for post-industrial development the patterns of reinvention have been similar: Post-industrial areas have been "reclaimed" by a vibrant "Creative Class" comprised of artists and professionals.

The proposed development of new transportation corridors with high-speed rail coupled with communications technology has the potential to revitalize dormant post-industrial cities and bring new sources of economic development to cities, transportation nodes, and emerging epicenters. Additionally, Smart Growth practices combined with the sustainable planning and design of cities and regions will promote denser, more compact, and more livable cities and communities in the future.

\section{Strategies for sustainable development}

Our research has shown that many mid-size cities in the U.S. have been successfully redeveloping their industrial districts since the early 1980s. Investigation focused primarily on post-industrial cities located in the Midwest in Missouri, Illinois, Wisconsin, and Minnesota. We discovered that mid-size cities are often able to successfully transform their industrial districts because they tend to be compact and have an existing infrastructure of city services and readily adaptable buildings that are robust and architecturally desirable. We also noted that transportation plays a vital role in revitalizing post-industrial cities and 
regions in Europe, and can serve as a model for U.S. cities and the development of $21^{\text {st }}$ Century sustainable "mega-regions".

Strategies that work include: 1) Facilitate smart growth practices by consolidating cities and focusing development; 2) Invest in urban infrastructures and services to promote smart cities and efficiency; 3) Develop creative capital of people, goods, and services to create economic diversity; 4) Strengthen public-private partnerships to leverage and sustain development; 5) Promote design quality and equitability that enhance quality of life and livability to attract people and investment; 6) Preserve and re-use existing buildings to promote sustainability and maintain a sense of place in existing neighborhoods and districts.

\subsection{Facilitate smart growth practices}

The term "post-industrial" was first popularized by Daniel Bell in which he forecast that mature national economies were moving and would continue to move from being manufacturing-based to service-based (Bell [2]). Don Carter, Director of the Remaking Cities Institute, believes that shrinking cites with wellplanned post-industrial redevelopment have the best attributes of "Smart Growth," including walkable neighborhoods, affordable housing, historic downtowns and main streets, strong universities and hospitals, cultural amenities, parks, unused infrastructure capacity, development density sufficient to support public transit, and abundant water (Carter [3]).

Karina Pallagst, Program Director of the Center for Global Metropolitan Studies, suggests that urban shrinkage in some cities is necessary due to the "complex...forces of globalization" (Pallagst [4]). Consequently, cities should recognize this phenomenon in "downsizing" urban areas and services. As cities sprawl, the urban metabolism they generate can actually become a negative force that eventually strangles the vitality of the city. Conversely, Richard Florida argues, "if geographical boundaries are respected, urban metabolism can enhance the vitality of the city both culturally and economically" (Florida [5]).

Shrinkage, geographic consolidation, and revitalization present the opportunity to maximize urban metabolism in post-industrial cities (Pallagst [4]). Urban metabolism is a phenomenon that occurs in cities when they are able to grow in GDP, innovation, and patent activity (Florida [5]). As they do this, their physical growth happens faster. This typically leads to rising congestion, housing and business costs. When cities sprawl, urban metabolism can eventually strangle the vitality of the city; but if geographical boundaries are respected, urban metabolism can enhance the vitality of the city both culturally and economically.

\subsection{Invest in urban infrastructures and services}

Development of new transportation and communications networks is already transforming the metabolism of entire regions by consolidating them both temporally and virtually. During the 1950s and 1960s, planners in cities throughout the U.S. were convinced that the survival of the modern city required 
that it take immediate steps to accommodate the projected enormous increase in private vehicle ownership (Garrick [6]). However, the expressway destroyed fabric of the city with its built history and heritage, and compromised its future by transporting people and jobs out of the city. John Norquist, CEO of the Congress for New Urbanism (CNU), emphasizes that cities be designed with transportation corridors that safely and efficiently handle all modes of transit, including walking, bicycling, mass transit, and automobiles (Norquist [7]).

In Lille, France, for example, its historic industrial center was transformed when its entire rail infrastructure was changed. In 1989 Euralille, a publicprivate partnership, conceived a vast program that will ultimately consist of more than $800,000 \mathrm{~m}^{2}$ (8.6 million $\left.\mathrm{ft}^{2}\right)$ of urban activities including shopping, offices, parking, a new TGV station, hotels, housing, a concert hall, and congress accommodation to be built on 120 hectares (297 acres) on the site of the former city fortifications by Vauban (Meade [8]). The new TGV line, which will link Lille, Brussels, and Paris, is projected on the location of the former fortifications now occupied by a proliferating periphérique. Rem Koolhaas of the Office of Metropolitan Architecture (OMA) insists that conventional urban "programs" of living, working, shopping, culture, and entertainment have become abstract in the sense that they are no longer connected to a place or a city. Instead "they will float and gravitate opportunistically to that site which offers the highest number and quality of connection - which seems nearest to all other places" (Partheus [9]).

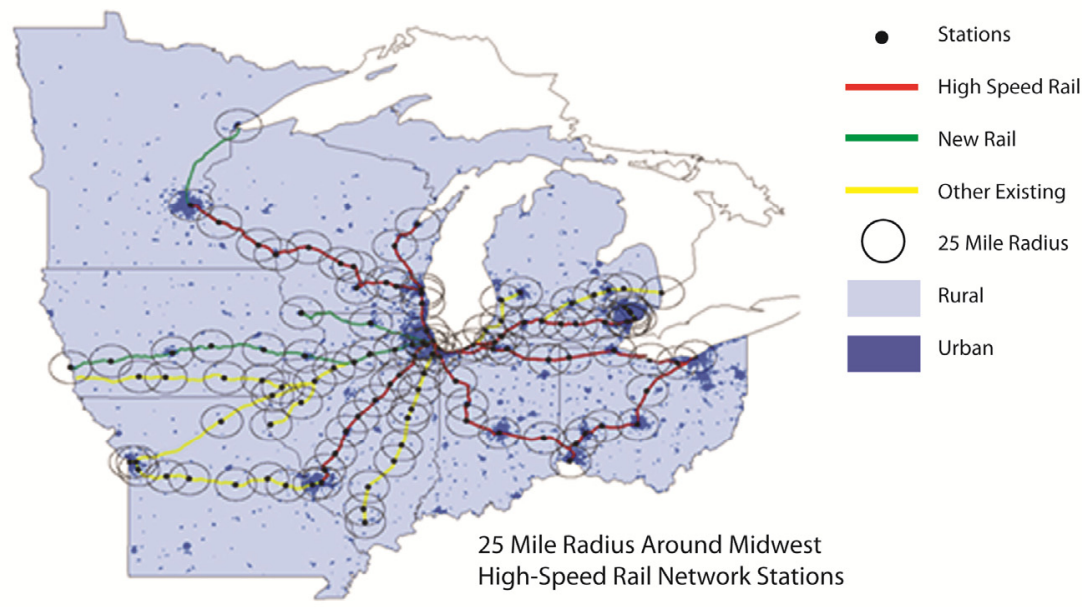

Figure 1: Proposed Midwest hub-and-spoke high-speed rail lines and epicenter nodes.

Planning is already underway for a high speed rail (HSR) system in the U.S. that will connect various cities and regions of the country. While existing rail 
corridors may be used at the initial stages of development, new corridors will also need to be created. In the Midwest, for instance, a Tri-State HSR corridor is proposed to link St. Louis, MO, Chicago, Milwaukee and Madison, WI, and Minneapolis/St. Paul, MN (Fig 1). In a report commissioned by the Midwest High Speed Rail Association (MHSRA), it is predicted that HSR will bring a $\$ 13.8$ billion increase in business sales, add 104,000 new jobs, and an additional $\$ 5.5$ billion in wages each year for the Chicago Metro area alone. It will also revitalize manufacturing by ramping up production of new trains, as well as creating new sectors for economic growth in agri-business, sustainable technology, medicine and bio-sciences, and manufacturing (EDR Group [10]).

When transportation is coupled with high-speed communication, such as broadband technology, mobile phones, and the global Internet, regional metabolisms can be increased in manifold ways. This includes the development of new services, technology, and clean-manufacturing industries that can be incorporated into sustainably planned cities, districts, and neighborhoods, as well as along existing and new transportation corridors. Table 1 illustrates the projected economic benefits of a Tri-State Midwest Regional Rail System (MWRRS) network.

Table 1: Community benefits of high-speed rail in the Midwest.

\begin{tabular}{lccc}
\hline State & $\begin{array}{c}\text { New Jobs } \\
\text { Permanent }\end{array}$ & $\begin{array}{c}\text { Permanent Household } \\
\text { Income (millions) }\end{array}$ & $\begin{array}{c}\text { Joint Development } \\
\text { Potential (millions) }\end{array}$ \\
Illinois & 24,200 & $\$ 480 \$ 2,227$ \\
Wisconsin & 9,570 & $\$ 173$ & $\$ 704$ \\
Minnesota & 1,570 & $\$ 31$ & $\$ 145$ \\
Missouri & 5,600 & $\$ 109$ & $\$ 480$ \\
\hline MWRRS & $\mathbf{5 7 , 4 5 0}$ & $\mathbf{\$ 1 , 0 9 6}$ & $\$ \mathbf{4 4 , 9 1 1}$
\end{tabular}

Source: Transportation Economics and Management Systems, Inc.

The conurbations of people and services expected at transportation nodes also will encourage density and promote economic growth. Transportation corridors can act as "spine" along which new programs and infrastructure can be developed without significantly compromising valuable land for agriculture and recreation. New development should be related as closely as possible with existing and new Perimeter Centers and Nodes to promote density and consolidate resources. Sustainable "Smart Growth" involves intelligent planning that begins with a well conceived transportation and service infrastructure. Programs, in turn, can be "attached" to this infrastructure as required.

While HSR is a key component of regional growth, the metabolism of the city also must be increased through the sustainable redevelopment of its existing infrastructure. As in transportation and the mega-region, this requires forging public-private partnerships among cities, developers, and industries. During the 1990s, for example, the city of St. Paul, Minnesota and Duke Energy Generation Services developed Ever-Green Energy, a wood-fired combined heat and power (CHP) cogeneration facility to produce clean, efficient, and renewable energy for the Lowertown District. Because it is a cooperatively funded, the community 
has an investment stake as well as the industry, which can also lead to more affordable energy.

\subsection{Develop creative capital}

Richard Florida defines the "Creative Class" as a knowledge-based group of young, educated, mobile professionals who are bringing new vitality and entrepreneurism to cities. We prefer the term "Creative Capital" to broaden Florida's definition to include people, goods, and services that can be used to increase urban and regional metabolisms.

One strategy to improve creative capital is to diversify the economy. In Pittsburgh, PA, for example, decisions made during the 1980s and 1990s to promote high-tech industries and research have increased its share of employment in the education and health services industries by 1.5 times larger than the U.S. employment (Miller and Rudick [11]).

Milwaukee, Wisconsin's Third Ward industrial district, developed in 1983, is a vibrant community of artists, young professionals, and empty nesters who have rediscovered the benefits of urban life (Fig. 2). Whereas Florida emphasizes urban development that attracts the well-educated professional class, such as upscale galleries and restaurants, Norquist believes that "craftsman, artists, and artisans can fit nicely with small-scale manufacturing" (Norquist [7]). Today, Milwaukee's Third Ward warehouse district includes galleries, pricey condos, shops and restaurants, but still retains the wholesale produce commission, machine tool shops, and even a small-scale steel producer. As a result of this economic and cultural diversity, the Third Ward has prospered adding over 2,000 new residents while retaining much of its industrial character.
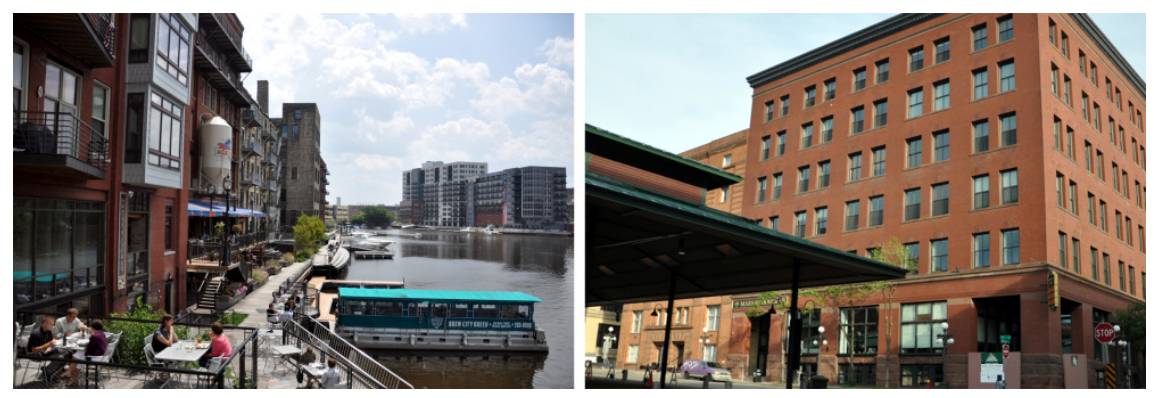

Figure 2: The redevelopment of the Third Ward in Milwaukee, WI (left) and the MarketHouse Condominiums in Lowertown, St. Paul, MN (right) was leveraged through the combination of public-private partnerships and the creative capital of people, goods, and services.

\subsection{Strengthen public-private partnerships}

The redevelopment of Lowertown in St. Paul, Minnesota in the early 1980s became a national model of successful central city revitalization through publicprivate partnerships (Fig. 2). Weiming Lu is an urban planner and past-president 
of the Lowertown Development Corporation. "To accomplish our mission," Lu explains, "the corporation focused on three types of activities: first as a design center to create a new vision for the area; second as a marketing office to make people believe in our vision and the market potential for the area and willing to invest; and, third, as a development bank to fill the gap in financing." $\mathrm{He}$ acknowledges the importance of forming strong public and private alliances in redevelopment of post-industrial districts; however, "physical renewal [by itself] does not bring social regeneration" (Lee [12]).

The development bank has been the economic lynchpin for Lowertown's social regeneration as well. Private investors are less risk-adverse when they know that cities will work with them to create incentives for development. Through persistent efforts, the Lowertown Corporation actually generated $\$ 750$ million in investment, or seven-and-a-half times the original goal. Through discipline and successful negotiations, the corporation attracted $\$ 5$ to $\$ 35$ dollars in public and private money for every dollar it invested in a project. The tax base increased six-fold from $\$ 850,000$ in 1979 to $\$ 5$ million in 2005. The project resulted in 2,600 housing units and added and retained 12,000 jobs (Lee [12]).

The concentration of old warehouses and factories has the potential for fostering a sense of place. Lu believes that new development should harmonize with the existing fabric of the community (Lee [12]). The North Loop or Warehouse District was originally the shipping hub of Minneapolis, Minnesota. It became the epicenter of its art scene during the 1980s until the area's buildings became more commercially desirable in the 1990s. Recent developments include modern mixed-use loft condominium and apartment buildings, adaptive re-use of the Gold Medal flour mills for a museum, and the addition of major new cultural buildings such as the Guthrie Theater, designed by Jean Nouvel, and Target Field, home of the Minnesota Twins professional baseball team. Again, these projects could be realized only through public-private partnerships.

\subsection{Promote good design for quality of life and livability}

There is growing evidence that good design enhances both the quality of life (QOL) of residents and the livability of cities. A livable city-suitable for human living - is one that is in balance where all of its parts and resources contribute to the quality of life of its inhabitants (Florida [5]). People benefit when consideration is given to the design of walkable, pedestrian-oriented neighborhoods and districts that attract businesses and people.

Canal Park in Duluth, Minnesota is an excellent example of a livable district where a former gritty industrial area has been transformed into a pedestrianfriendly mixed-use community of shops, restaurants, residential lofts, and businesses. A Maritime Museum and boardwalk (Fig. 3) located along the inner harbor of Lake Superior, in addition to an existing landmark, the aerial lift bridge, have made Canal Park a tourist destination. 

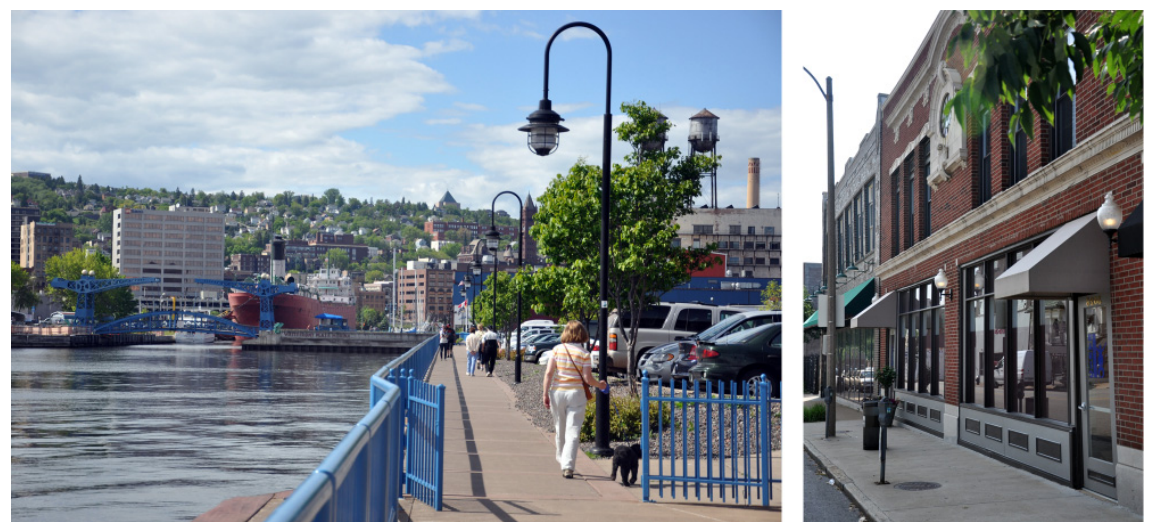

Figure 3: Pedestrian-friendly streets and preservation of existing buildings, such as in Canal park, Duluth, MN (left) and Midtown Alley, St. Louis, MO (right), promote livabilty and create a sense of place.

\subsection{Preserve existing buildings to create sustainable cities}

To achieve sustainable cities, historic preservation is the foundation and initial step to redeveloping the post-industrial district in the American city (Kapp [13]). Rehabilitating the existing buildings, streets and open space is not only practical; it is sustainable both from an economic and environmental point-of-view. It creates an aesthetically pleasing environment that utilizes the best attributes of the district - its sense-of-place. Attention to scale, careful selection of building materials, and maintaining the historic character of cities can promote greater livability, provide a sense of well-being through the creation of place, and encourage people to live, work, and shop in urban areas. Furthermore, preserving and adapting existing buildings for new uses is the first step in developing sustainable neighborhoods and communities. Razing old buildings and replacing them with new construction is often detrimental to the historic continuity of the city and wastes valuable non-renewable energy and material resources. Recycling and re-purposing of old buildings, however, conserves embodied energy, preserves the historic and aesthetic character of existing buildings and neighborhoods, and enhances the sense of "place" in communities by maintaining continuity with the past.

Midtown Alley is an historic neighborhood in the 3000 block of Locust Street in St. Louis that connects St. Louis University with the downtown (Fig. 3) (Midtown Alley [14]). The neighborhood went into decline after its heyday in the 1920s, when it was known as Auto Row, and later with the introduction of public housing projects during the 1960s and 1970s. The housing was razed in the late 1990s, which prepared the way for the revival of the district.

Jassen Johnson is a 32-year-old real estate developer and head of Renaissance Development Associates in St. Louis who has spearheaded a $\$ 70$ million redevelopment of almost 40 buildings in the historic Midtown Alley neighborhood, which encompasses a three-by-six-block area that is being 
redeveloped by RDA in partnership with DN Development (St. Louis Business Journal [15]).

Johnson points out that Midtown Alley is a community with a distinct character that is attracting an emerging creative class of entrepreneurs (Armstrong [16]). Instead of pursing retail clients - as many developers might ordinarily do-Renaissance wooed creative service agencies such as advertising companies, photographers, and the like. It convinced them that relocating from the suburbs and other locations to Midtown would make them more accessible to their clients, and that they would benefit financially and professionally from being located in an historic neighborhood. The success of these creative enterprises has attracted other entrepreneurs to the area, and today people consider Midtown Alley a trendy place to live and work.

Wireworks Lofts located at Lafayette Square, is an adaptive reuse of an existing factory building that was gutted by fire. Like Midtown Alley, it is a joint-venture between Renaissance and the ND Group. In this case, only the original exterior walls could be salvaged and new residential lofts and a commercial complex were created within. Wireworks features "stylish contemporary loft units" that range from 800 to 1,670 square feet with "high ceilings, terrific views, exposed brick, and large windows" (Wireworks Lofts [17]). Maintaining the exterior walls also allowed the developers to create a private outdoor courtyard gathering space for residents with a swimming pool and a landscaped patio area.

Renaissance recently completed the second phase of a $\$ 9$ million dollar mixed-use development called REO Loft Development at the corner of Compton and Locust, which features three commercial spaces, seven residential loft apartments and two live/work units. Redevelopment of the PW Shoe Lofts), a \$10 million project at the corner of Locust and Theresa, also was completed in July 2010. The building features 33 loft apartments, two live/work units and restaurant space for the locally owned Field House Sports Bar and Grill. And The Linen Lofts at 3124 Olive, which underwent a \$5.5 million rehab, was completed in late 2005. Johnson estimates that it will take an additional \$20 million of development to make Midtown alley sustainable (St. Louis Business Journal [15]). Future High-Speed Rail service connecting Chicago to St. Louis coupled with revitalization of mass-transit and trolley lines in St. Louis itself will further redevelopment efforts and is expected to increase the overall economic metabolism of the city and region.

\section{Conclusion}

OMA contends that the "floating programs" and transportation hub of Euralille will "define a new urban condition which is at the same time local and global." As we consider alternatives to the planning, development, and design of postindustrial cities and regions we must also consider the roles that new modes of transportation and communications technology will have on the economic and social transformations of urban centers and people at the scale of the megaregion. 
High-speed rail has the potential to revitalize dormant post-industrial cities and bring new sources of economic development to cities, transportation nodes, and emerging epicenters. Transportation not only links cities and regions physically, but when combined with communications, such as the Internet and broadband technology, allows regions to prosper by attracting capital investment, fostering new industries and technologies thereby creating wealth and jobs, and reinvigorate the metabolic flow along transportation corridors and nodes.

Smart Growth practices combined with the sustainable planning and design of cities and regions will promote denser, more compact, and more livable cities and communities in the future. "Clean" technologies will promote energyefficient buildings and urban environments. Post-industrial districts, serviced by transportation networks, will continue to be adapted to new uses that blend living, working, and light manufacturing with schools, civic, and cultural institutions, in addition to shopping and entertainment. Business and creative incubators can be developed in collaboration with continuing education programs that will retrain skilled workers and develop new economic opportunities for growth, as well as bring educational opportunities to center city districts.

Maintaining the historic character of districts by preserving and repurposing existing buildings is the first step in developing sustainable cities. It also makes good economic sense since many of these buildings were built robustly using quality materials and, consequently, are adaptable to almost any usage. When derelict buildings are razed, their materials can also be recycled for new construction.

Finally, districts and cities also need to be linked through transportation networks to regional health care and bio-research campuses that will be vital in promoting health and well-being for urban and regional residents from infancy through old age. This process, however, will require new ways to conceive and plan cities and regions, which will produce economic, social, and cultural benefits for all stakeholders.

\section{References}

[1] Fisher, E. O’N. \& Rupert, P. C., The decline of manufacturing employment in the United States, pp. 1-21, 2005, Online. http://www.calpoly.edu /efisher/fr20050327.pdf Retrieved August 7, 2011.

[2] Bell, D., The Coming of the Post-Industrial Society: A Venture in Social Forecasting, Basic Books: New York, 1973.

[3] Carter, D., Hope for the future of the post-industrial city (Chapter 1). SynergiCity: Reinventing the Post-Industrial City, ed. P. H. Kapp \& P. J. Armstrong, Champaign: University of Illinois Press, Champaign, IL, pp. 526, 2012.

[4] Pallagst, K., Shrinking cities: Planning challenges from an international perspective. Cities Growing Smaller, ed. S. Rugare \& T. Schwarz, Kent, OH: Kent State University, pp. 6-16, 2008.

[5] Florida, R.L., Cities and the creative class, Routledge, London, 2005. 
[6] Garrick, N., The sustainable transportation agenda for post-industrial cities (Chapter 10). SynergiCity: Reinventing the Post-Industrial City, ed. P. H. Kapp \& P. J. Armstrong, Champaign: University of Illinois Press, pp. 221$251,2012$.

[7] Norquist, J., Restoring urbanism in U.S. cities (Chapter 6). SynergiCity: Reinventing the Post-Industrial City, ed. P. H. Kapp \& P. J. Armstrong, Champaign: University of Illinois Press, pp. 132-141, 2012.

[8] Meade, M. K., Euralille: The instant city, The Architecture Review, December, 1994, Bnet, The CBS Interactive Network. http://www.findarticles.com/p/articles/mi_m3575/is_n_1174_v196/ai_1656 1934/?tag=mantle_skin; content Retrieved August 18, 2011.

[9] Parthius, F., Euralille 2010, Euralille, France, Lille, 1994, Office of Metropolitan Architecture, 2011. http://www.oma.eu/index.php? option=com_project\&id=211\&Itemid=10 Retrieved on August 18, 2011.

[10] Economic Development Research (EDR) Group, The economic impacts of high speed rail: Transforming the Midwest, Boston, Mass., April 28, 2011. http://www.prnewswire.com/news-releases/midwest-high-speed-rail-couldbring-43-million-annual-riders-104000_new_jobs-and-nearly-300-billionin-new-business-sales-over-30-years-120856219.html. Retrieved September 15, 2007.

[11] Miller, C. and B. Rudick, The Pittsburgh Metropolitan Statistical Area, Federal Reserve Bank of Cleveland, 2007. http://www.clevelandfed.org /research/trends/2007/0407/01regact_032607.cfm.

[12] Lee, A. J., An interview with Weiming Lu. CRM: The Journal of Heritage Stewardship, 5(2), Summer, pp. 1-6, 2008 http://sapiens.revues.org/ index $169 \mathrm{html}$.

[13] Kapp, P. H., Historic preservation: The foundation of SynergiCity (Chapter 3). SynergiCity: Reinventing the Post-Industrial City, ed. P. H. Kapp \& P. J. Armstrong, SynergiCity: Reinventing the Post-Industrial City, Champaign: University of Illinois Press, pp. 55-78, 2012.

[14] Midtown Alley, brochure. http://mditownalley.com/image4s/ Midtown_Alley_Brochure.pdf. Retrieved October 11, 2011.

[15] St. Louis Business Journal, $\$ 70$ million redevelopment revives Midtown Alley, St. Louis, MO, September, 26, 2010. http//www.bizjournals/ stlouis/stories/2010/09/27/focus2.html Retrieved October 11, 2011.

[16] Armstrong, P. J., Creating urban metabolism (Chapter 4). SynergiCity: Reinventing the Post-Industrial City, ed. P. H. Kapp \& P. J. Armstrong, Champaign: University of Illinois Press, pp. 78-107, 2012.

[17] Wireworks Lofts, Lofts in the square, St. Louis, MO, 2005. http://www.wireworkslofts.com/index.html Retrieved January 20, 2012. 